\title{
The impact of leverage on firm investment: Canadian evidence
}

\author{
Varouj A. Aivazian ${ }^{\mathrm{a}, *}$, Ying $\mathrm{Ge}^{\mathrm{b}}$, Jiaping Qiu ${ }^{\mathrm{c}}$ \\ ${ }^{a}$ Department of Economics and Rotman School of Management, University of Toronto, 150 St. George Street, \\ Toronto, ON, Canada M5S $3 G 7$ \\ ${ }^{\mathrm{b}}$ School of International Trade and Economics, University of International Business and Economics, \\ Beijing, P.R. China \\ ${ }^{\mathrm{c}}$ Finance Area, School of Business and Economics, Wilfrid Laurier University, 75 University Avenue West, \\ Waterloo, ON, Canada N2L $3 C 5$
}

Received 1 March 2003; received in revised form 1 April 2003; accepted 1 May 2003

Available online 15 August 2003

\begin{abstract}
This study examines the impact of financial leverage on the firms' investment decisions using information on Canadian publicly traded companies. It shows that leverage is negatively related to investment and that this negative effect is significantly stronger for firms with low growth opportunities than those with high growth opportunities. The paper tests the robustness of these results using alternative empirical models and, in addition, uses the instrumental variable approach to deal with the endogeneity problem inherent in the relationship between leverage and investment. The results provide support to agency theories of corporate leverage, and especially the theory that leverage has a disciplining role for firms with low growth opportunities.
\end{abstract}

(C) 2005 Elsevier B.V. All rights reserved.

JEL classification: $\mathrm{G} 32$

Keywords: Leverage; Investment; Canada; Corporate finance

\section{Introduction}

The impact of financial leverage on a firm's investment decision is a central issue in corporate finance. If the Modigliani and Miller (1958) irrelevance proposition is correct, a firm's investment policy should depend solely on such factors as the future state of demand, the firm's production technology, the market interest rate, that is, on fundamental

* Corresponding author. Tel.: +1-416-978-2375; fax: +1-416-978-6713.

E-mail address: aivazian@chass.utoronto.ca (V.A. Aivazian). 
determinants of profitability, cash flow, and net worth. A large theoretical and empirical literature has challenged this position, arguing that financing considerations significantly complicate the investment relationship, introducing important determinants beyond neoclassical fundamentals. In theory, finance tends to affect real investment decisions when there are missing or incomplete markets due to transaction costs and asymmetric information - that is, outside a Miller-Modigliani world. ${ }^{1}$ In a world with incomplete markets, agency problems arising from interactions between shareholders, debt holders, and management give rise to underinvestment or overinvestment incentives; these agency problems introduce a range in which investment may not be fully responsive, or may be over-responsive, to changes in economic fundamentals.

The present paper provides new evidence on the relationship between financial leverage and investment and extends the prior literature in several important dimensions pertaining to empirical methodology, including the treatment of the so-called problem of endogeneity, in the relationship between investment and leverage. It examines the relationship for Canadian publicly traded companies. Previous studies have been mostly restricted to firms in the United States; Canadian evidence is of particular interest given that Canada has similar institutions and regulations to the United States. This study allows us to compare results across two similar yet quite independent samples.

Previous studies of the relationship between leverage and growth, such as McConnell and Servaes (1995) and Lang et al. (1996), use pooling regressions and in effect ignore individual firm effects. Such an approach may not fully identify the impact of leverage on growth if the relationship is also governed by unobservable individual firm characteristics. This paper extends the earlier analyses by using a panel data methodology to control for heterogeneity among individual firms, and tests the robustness of the results using alternative empirical models. It finds that a pooling regression tends to underestimate the impact of leverage on investment and that the fixed-effects model is the most appropriate specification. The results of the paper indicate that leverage has a significantly negative impact on investment for Canadian firms and that it has a stronger negative impact on firms with low growth opportunities. Our results are similar to earlier ones for the US, such as those of Lang et al. (1996).

This paper utilizes the instrumental variable approach to address the endogeneity problem pertaining to the relationship between leverage and investment. To our knowledge, this is the first paper that employs this approach to study the link between leverage and firm investment. The empirical results indicate that the negative relationship between leverage and investment is maintained under the instrumental variable approach suggesting that endogeneity cannot explain away the negative relationship between leverage and investment.

The paper is organized as follows. Section 2 outlines possible theoretical links between financial leverage and capital investment and reviews extant empirical results. Section 3 describes the data and Section 4 reports the empirical results from a panel data specification. Section 5 presents results from a two-stage regression approach, while Section 6 tests the robustness of the results. Section 7 summarizes and concludes the paper.

\footnotetext{
1 Taxes are, of course, another source of interaction between finance and investment.
} 


\section{The link between leverage and investment}

In a seminal paper, Myers (1977) analyzes possible externalities generated by debt on shareholders' (and management's) optimal investment strategy. The idea is that debt overhang reduces the incentives of the shareholder-management coalition in control of the firm to invest in positive net-present-value investment opportunities, since the benefits accrue, at least partially, to the bondholders rather than accruing fully to the shareholders. Hence, highly levered firms are less likely to exploit valuable growth opportunities as compared to firms with low levels of leverage. A related underinvestment theory centers on a liquidity effect in that firms with large debt commitments invest less irrespective of the nature of their growth opportunities. ${ }^{2}$

In theory, even if debt creates potential underinvestment incentives, the effect could be attenuated by the firm taking corrective action and lowering its leverage, if future growth opportunities are recognized sufficiently early. ${ }^{3}$ Leverage is optimally reduced by management ex ante in view of projected valuable ex post growth opportunities, so that its impact on growth is attenuated. Thus, a negative empirical relation between leverage and growth may arise even in regressions that control for growth opportunities because managers reduce leverage in anticipation of future investment opportunities. Leverage simply signals management's information about investment opportunities. We refer to the possibility that leverage might proxy for growth opportunities as the endogeneity problem.

Another possible agency problem discussed in literature is the "overinvestment" problem where the conflict is between management and shareholders; ${ }^{4}$ the argument is that managers have a propensity to expand the scale of the firm even if that means undertaking poor projects and reducing shareholder welfare. Management's ability to carry out such a policy is constrained by the availability of free cash flow, and this constraint can be further tightened via debt financing. The issuance of debt precommitts the firm to pay cash as interest and principal, forcing managers to service such commitments with funds that may have otherwise been allocated to poor investment projects. Thus, leverage is one mechanism for overcoming the overinvestment problem suggesting a negative relationship between debt and investment for firms with weak growth opportunities.

There is support for both the overinvestment and the underinvestment theories in the extant empirical literature. McConnell and Servaes (1995) examine a large sample of non-financial US firms for the years 1976, 1986, and 1988. For each year, they separate their sample into two groups, those with strong growth opportunities and those with weak growth opportunities. They show that corporate value is negatively correlated with leverage for firms with strong growth opportunities (indicated by high Tobin's Q), and positively correlated with leverage for firms with weak growth opportunities (or low Tobin's Q). Their results are consistent with the hypothesis that

\footnotetext{
2 See Lang et al. (1996).

3 Alternatively, if transaction costs of bargaining are small, recontracting between debt holders and equity holders internalizes potential externalities generated by leverage, in effect overcoming the underinvestment problem. See Aivazian and Callen (1980).

4 See Jensen (1986) and Stulz (1990).
} 
leverage induces underinvestment and reduces firm value, as well as the hypothesis that leverage attenuates overinvestment and increases firm value. Lang et al. (1996) analyze a large sample of US industrial firms over the period 1970-1989 and find a strong negative relation between leverage and subsequent investment, but only for firms with weak growth opportunities (with Tobin's Q less than one). Again, their results are consistent with the hypothesis that leverage attenuates incentives to invest in poor projects. To address the endogeneity issue mentioned earlier, that leverage might proxy for growth opportunities, Lang et al. (1996) distinguish between the impact of leverage on growth in a firm's core business from that in its non-core business. They argue that if leverage is a proxy for growth opportunities, its contractionary impact on investment in the core segment of the firm should be much more pronounced than in the non-core segment. However, they find that the impact of leverage on growth tends to be not significantly different across core and non-core segments, suggesting that leverage is not simply a proxy for growth opportunities.

The differences in existing empirical results for high Q and low Q companies may be due to $\mathrm{Q}$ serving as a proxy for ease of access to the capital market. High Q firms (those with strong growth prospect) have expectations of higher cash flows, or net worth, and this may reduce moral hazard and adverse selection problems inherent in the supply of credit to the firm in the capital market. For such firms, leverage is less of a constraint on investment since a firm with strong growth prospects can more easily refinance and recapitalize in the capital market. For firms with low Q, leverage would be a tighter constraint limiting investment, since such firms would find it harder to recapitalize given their perceived weak growth prospects. However, this argument does not explain the positive association between leverage and firm value for low Q firms.

\section{Data and description of variables}

The data used in this paper are the Compustat Canadian 1999 Annual File. This file contains financial, statistical, and market information on 1035 major Canadian industrial companies existing at the end of 1999. The 1999 annual data file covers the period from 1982 to 1999 . The average age of the firms in the sample is 8.2. After checking and screening for apparent coding errors and missing variables, an unbalanced panel of 6231 observations of 863 firms remained for estimation.

We use two alternative measures of leverage. One is book value of total liabilities divided by book value of total assets, while the other is book value of long-term debt divided by total assets. ${ }^{5}$ Both measures have been used in the literature. The first measure does not distinguish between short-term debt and long-term debt while the second one emphasizes the dominant role of long-term debt as a determinant of investment. We try both definitions in our estimation. Tobin's Q is defined as the market value of total assets of the firm divided by the book value of assets and is a proxy for growth opportunities. We calculate the market value of the firm as the sum of total liabilities, the value of the

\footnotetext{
5 Lang et al. (1996) and Opler and Titman (1994) discuss the reasons for the use of book values.
} 
Table 1

Summary statistics for growth, leverage, and investment opportunities

\begin{tabular}{lccccc}
\hline & Mean & $\begin{array}{l}\text { 25th } \\
\text { percentile }\end{array}$ & Median & $\begin{array}{l}\text { 75th } \\
\text { percentile }\end{array}$ & $\begin{array}{l}\text { Standard } \\
\text { deviation }\end{array}$ \\
\hline Net investment $/$ Fixed assets $t-1_{t}$ & 0.17 & -0.01 & 0.06 & 0.21 & 0.54 \\
Cash flow $_{t} /$ Total assets $_{t-1}$ & 0.16 & 0.02 & 0.17 & 0.36 & 1.38 \\
Tobin's Q $_{t-1}$ & 1.75 & 1.00 & 1.22 & 1.75 & 2.20 \\
(Long term debt/Total assets) $_{t-1}$ & 0.18 & 0.01 & 0.15 & 0.29 & 0.17 \\
(Total liabilities/Total assets) $t-1$ & 0.48 & 0.30 & 0.50 & 0.65 & 0.24 \\
(Net sales/Fixed assets) $t-1$ & 4.50 & 0.43 & 1.62 & 4.89 & 9.70 \\
\hline
\end{tabular}

The sample consists of all firms listed in the Compustat Canadian 1999 Annual File. The 1999 annual data file covers the period of $1982-1999$ with an unbalanced panel of 6231 observations of 863 firms.

common stocks, and the estimated value of preferred stocks. ${ }^{6}$ Cash flow is measured as the sum of earnings before extraordinary items and depreciation, and Sale is defined as net sales deflated by net fixed assets.

Table 1 provides descriptive information for the investment and the financial data. Inspection of the table reveals a high variation of investment among the Canadian firms. The mean of the ratio of net investment to fixed assets is 0.17 , while the standard deviation is 0.54 , which is three times the mean. The sample average Tobin Q of 1.75 reflects market expectations of strong growth opportunities for Canadian firms over this sample period, which is reasonable for the period of the 1990s. The mean of the ratio of long-term debt to total assets is 0.18 , while the ratio of total liabilities to total assets is 0.48 ; this suggests that there is a significant reliance on short-term debt finance by Canadian firms.

\section{The impact of leverage on investment}

\subsection{Baseline specification}

We estimate a reduced form investment equation to examine the impact of leverage on investment. The specification is similar to Lang et al. (1996) but is extended to a panel setting. Specifically, we estimate the following equation:

$$
\begin{aligned}
I_{i, t} / K_{i, t-1}= & \alpha+\lambda_{t}+\beta\left(\mathrm{CF}_{i, t} / K_{i, t-1}\right)+\delta Q_{i, t-1}+\eta \operatorname{LEVERAGE}_{i, t-1} \\
& +\varphi\left(\mathrm{SALE}_{i, t-1} / K_{i, t-1}\right)+\mu_{i}+\varepsilon_{i, t}
\end{aligned}
$$

where $I_{i, t}$ is the net investment of firm $i$ at time $t ; K_{i, t-1}$ is lagged net fixed assets; $\mathrm{CF}_{i, t}$ is cash flow of firm $i$ at time $t ; Q_{i, t-1}$ is lagged Tobin's Q; LEVERAGE ${ }_{i, t-1}$ is lagged leverage; $\mathrm{SALE}_{i, t-1}$ stands for lagged net sales of firm $i ; \alpha$ is a constant; $\lambda_{t}$ is a set of time dummy controlling for possible differences in the macroeconomic environment of each year; $\mu_{i}$ is the individual effect of firm $i$, and $\varepsilon_{i, t}$ is the error term.

\footnotetext{
6 The market value of preferred stocks is estimated as preferred dividend times 10. Himmelberg et al. (1999) use the same definition. The results presented here are robust to alternative definitions of market value.
} 
Lang et al. (1996) assume that the unobservable individual effect is zero and use a pooling regression to estimate the investment equation. Most other studies of the relationship between leverage and investment also use the pooling regression method and, to our knowledge, none examines the robustness of the results using other methodologies. The assumption of zero unobservable individual effect is too strong given that there is large heterogeneity across industries and across firms within the same industry. To control for individual firm heterogeneity, we employ a random effect as well as a fixed effect model. In addition, we statistically test which empirical model is most suitable for estimating investment behavior.

Table 2 reports the regression results for the investment equation using the two alternative measures of leverage and three different methodologies: pooling regression, random effect model, and fixed effect model. The results show that leverage has a negative impact on investment at the $1 \%$ significance level. This negative leverage-investment relationship is robust for different leverage measures and empirical models. The point estimates range from -0.226 to -0.441 , suggesting that the investment to capital ratio decreases by about 0.0226 to 0.0441 when the leverage level increases by 0.1 . The impacts of the other variables on investment have the expected signs: Tobin's Q, which measures growth opportunities, has a significant positive impact on investment and the sensitivity of investment to cash flow is also positive and significant. Lagged sales are found to have a positive and significant effect on investment.

To identify which empirical methodology-pooling, random effect, or fixed effect regression - is most suitable, we perform two statistical tests: the first is the Lagrangian Multiplier (LM) test (Breusch and Pagan, 1980) of the random effect model. The null hypothesis is that the individual effect, $\mu_{i}$, is 0 . The chi-square statistics are reported in Row 8 of Table 2, and are equal to 281.82 and 258.4, respectively, for the two alternative definitions of leverage. Thus, the null hypothesis is rejected at the $1 \%$ significance level for both measures of leverage. The results suggest that the cohort effect is not zero and that the pooling regression is not suitable in this case. If we use the ratio of long-term debt to total assets as the measure of leverage, the regression coefficient on leverage from the pooling regression is equal to -0.226 and is significant at the $1 \%$ level. The regression coefficients on leverage from the random and fixed effect model are -0.441 and -0.356 , respectively. The coefficients estimated from the pooling regression are much smaller than those estimated from the random or the fixed effect models suggesting that ignoring individual firm effects leads to an under-estimation of the impact of leverage on investment.

Second, we conduct the Hausman specification test (Hausman, 1978) to compare the fixed effect and the random effect models. If the model is correctly specified and if individual effects are uncorrelated with the independent variables, the fixed effect and random effect estimators should not be statistically different. The statistics are reported in Row 9 of Table 2 and the null hypothesis is rejected at the $1 \%$ significance level. The results suggest that the fixed effect model is most appropriate in estimating the investment equation.

We next address econometric issues that might affect the estimation of the fixed effect model. First, there is a possibility of high correlations among the independent variables. For example, Tobin's Q represents growth opportunities and may affect the leverage decision. An improvement in a firm's growth prospects (e.g. in Tobin's Q) emanating from increased demand, or in its marginal efficiency of investment, induces an increase in 
Table 2

Regression analysis of investment equation

\begin{tabular}{|c|c|c|c|c|c|c|c|c|}
\hline & \multicolumn{4}{|c|}{ Leverage $=(\text { Long term debt/Total assets })_{t-1}$} & \multicolumn{4}{|c|}{ Leverage $=(\text { Total liabilities } / \text { Total assets })_{t-1}$} \\
\hline & Pooling & $\begin{array}{l}\text { Fixed } \\
\text { effect }\end{array}$ & $\begin{array}{l}\text { Random } \\
\text { effect }\end{array}$ & $\begin{array}{l}\text { FE with } \\
\text { AR (1) }\end{array}$ & Pooling & $\begin{array}{l}\text { Fixed } \\
\text { effect }\end{array}$ & $\begin{array}{l}\text { Random } \\
\text { effect }\end{array}$ & $\begin{array}{l}\text { FE with } \\
\text { AR (1) }\end{array}$ \\
\hline Intercept & $\begin{array}{l}0.229 * * * \\
(5.23)\end{array}$ & $\begin{array}{l}0.131^{* * *} \\
(5.65)\end{array}$ & $\begin{array}{l}0.201 * * * \\
(7.41)\end{array}$ & $\begin{array}{l}-0.479 * * * \\
(3.30)\end{array}$ & $\begin{array}{l}0.316^{* * *} \\
(6.43)\end{array}$ & $\begin{array}{l}0.204 * * * \\
(6.80)\end{array}$ & $\begin{array}{l}0.277 * * * \\
(8.97)\end{array}$ & $\begin{array}{l}0.281 * * * \\
(4.46)\end{array}$ \\
\hline Leverage & $\begin{array}{l}-0.226^{* * *} \\
(3.95)\end{array}$ & $\begin{array}{l}-0.441 * * * \\
(7.46)\end{array}$ & $\begin{array}{l}-0.356^{* * *} \\
(6.74)\end{array}$ & $\begin{array}{l}-0.302 * * * \\
(4.96)\end{array}$ & $\begin{array}{l}-0.286^{* * *} \\
(6.33)\end{array}$ & $\begin{array}{l}-0.335^{* * *} \\
(7.13)\end{array}$ & $\begin{array}{l}-0.320^{* * *} \\
(7.94)\end{array}$ & $\begin{array}{l}-0.334 * * * \\
(8.21)\end{array}$ \\
\hline Tobin's $\mathrm{Q}_{t-1}$ & $\begin{array}{l}0.043^{* * * *} \\
(3.12)\end{array}$ & $\begin{array}{l}0.053 * * * \\
(13.53)\end{array}$ & $\begin{array}{l}0.048 * * * \\
(13.86)\end{array}$ & $\begin{array}{l}0.063 * * * \\
(12.29)\end{array}$ & $\begin{array}{l}0.039 * * * \\
(2.96)\end{array}$ & $\begin{array}{l}0.054 * * * \\
(13.85)\end{array}$ & $\begin{array}{l}0.048 * * * \\
(13.82)\end{array}$ & $\begin{array}{l}0.043 * * * \\
(12.14)\end{array}$ \\
\hline $\begin{array}{l}\text { Cash flow }_{t} / \\
\text { Total } \text { assets }_{t-1}\end{array}$ & $\begin{array}{l}0.015 \\
(1.01)\end{array}$ & $\begin{array}{l}0.022 * * * \\
(3.12)\end{array}$ & $\begin{array}{l}0.024 * * * \\
(4.04)\end{array}$ & $\begin{array}{l}0.020 * * * \\
(2.84)\end{array}$ & $\begin{array}{l}0.017 \\
(1.12)\end{array}$ & $\begin{array}{l}0.021 * * * \\
(3.02)\end{array}$ & $\begin{array}{l}0.024 * * * \\
(4.11)\end{array}$ & $\begin{array}{l}0.026^{* * * *} \\
(4.47)\end{array}$ \\
\hline $\begin{array}{l}\text { Sale }_{t-1} / \\
\quad \text { Fixed assets } \\
t-1\end{array}$ & $\begin{array}{l}-0.003 * \\
(1.83)\end{array}$ & $\begin{array}{l}0.009 * * * \\
(7.11)\end{array}$ & $\begin{array}{l}0.003 * * * \\
(2.88)\end{array}$ & $\begin{array}{l}0.012 * * * \\
(8.48)\end{array}$ & $\begin{array}{l}-0.002 \\
(0.92)\end{array}$ & $\begin{array}{l}0.010 * * * \\
(7.79)\end{array}$ & $\begin{array}{l}0.004 * * * \\
(4.21)\end{array}$ & $\begin{array}{l}0.003 * * * \\
(3.14)\end{array}$ \\
\hline $\begin{array}{l}\text { LM test } \\
\text { Hausman test }\end{array}$ & \multicolumn{4}{|c|}{$\mathrm{Chi}^{2}(1)=281.81 * * *$} & \multicolumn{4}{|c|}{$\mathrm{Chi}^{2}(1)=258.46^{* * *}$} \\
\hline $\begin{array}{l}\text { Observations } \\
\text { (Groups) }\end{array}$ & 6231 & $\begin{array}{l}6231 \\
(863)\end{array}$ & $\begin{array}{l}6231 \\
(863)\end{array}$ & & 6231 & $\begin{array}{l}6231 \\
(863)\end{array}$ & $\begin{array}{l}6231 \\
(863)\end{array}$ & \\
\hline Adj. $R^{2}$ & 0.054 & 0.089 & 0.085 & & 0.064 & 0.088 & 0.085 & \\
\hline
\end{tabular}


investment. Such a change may, however, also affect the supply of financing to the firm to the extent that its improved prospects help overcome informational problems facing the firm on the credit market. In estimating the relationship between investment and financing, it is, therefore, necessary to identify meaningful measures correlated with either the demand side or the supply side, but not both. Tobin's Q also represents firm value and hence may be affected by leverage. The high correlation among the variables may affect the efficiency of the estimated coefficients. The correlations among the independent variables are reported in Table 3; they are generally less than 0.30 , suggesting that collinearity is not a serious problem.

Second, the variances of the error terms are possibly not constant across firms. One possible source of heteroscedasticity is that the variances of error terms are likely correlated with firm size. Given that all variables have been deflated by lagged net fixed assets, this problem is alleviated. We also use White's correction for heteroscedasticity to get consistent standard errors. The reported $t$-statistics in all the tables are based on consistent standard errors.

Third, there may be correlation of error terms across periods. To deal with this problem, we assume first-order autocorrelation: $\varepsilon_{i, t}=\rho \varepsilon_{i, t-1}+z_{i, t}$, where $z_{i, t}$ is independently and identically distributed. The results of the fixed effect model with the first-order autocorrelation are reported in columns 5 and 9 of Table 2. The estimated coefficients are similar to those estimated from the fixed effect model without controlling for autocorrelation in the error term.

\subsection{Growth opportunities and the role of leverage}

We have shown that leverage has a significant negative effect on investment, suggesting that capital structure plays an important role in the firms' investment policies. As discussed earlier, Myers (1977) argued that leverage could have a negative effect on investment because of an agency problem between shareholders and bondholders. If managers work in the interest of shareholders, they may give up some positive net present value projects due to debt overhang. The theories of Jensen (1986), Stulz (1990), and Grossman and Hart (1982) also suggest a negative relationship between leverage and

Table 3

Correlation among independent variables

\begin{tabular}{|c|c|c|c|c|c|}
\hline & $\begin{array}{l}\text { Cash } \text { flow }_{t} / \\
\text { Total assets } \\
t-1\end{array}$ & $\begin{array}{l}\text { Tobin's } \\
\mathrm{Q}_{t-1}\end{array}$ & $\begin{array}{l}\text { (Long term debt/ } \\
\text { Total assets })_{t-1}\end{array}$ & $\begin{array}{l}\text { (Total liabilities/ } \\
\text { Total assets) })_{t-1}\end{array}$ & $\begin{array}{l}(\text { Net sales/ } \\
\text { Fixed assets })_{t-1}\end{array}$ \\
\hline $\begin{array}{l}\text { Cash flow }_{t} / \\
\text { Total } \text { assets }_{t-1}\end{array}$ & 1.00 & - & - & - & - \\
\hline Tobin's $\mathrm{Q}_{t-1}$ & -0.18 & 1.00 & - & - & - \\
\hline $\begin{array}{l}\text { (Long term debt/ } \\
\text { Total assets })_{t-1}\end{array}$ & 0.01 & -0.19 & 1.00 & - & - \\
\hline $\begin{array}{l}\text { (Total liabilities/ } \\
\quad \text { Total assets) })_{t-1}\end{array}$ & 0.14 & -0.25 & 0.64 & 1.00 & - \\
\hline $\begin{array}{l}\text { (Net sales/ } \\
\quad \text { Fixed assets })_{t-1}\end{array}$ & 0.29 & -0.04 & -0.17 & 0.16 & 1.00 \\
\hline
\end{tabular}


investment, but their arguments are based on agency conflicts between managers and shareholders. They argue that firms with free cash flow but low (or no) growth opportunities may nevertheless invest (overinvest) in that the manager may take on projects with negative net present value. However, such a strategy is costly to the manager, if the capital market takes into account such potential opportunism, or there is a takeover of the firm by another company; managers have an incentive, therefore, to precommit and increase leverage and pay out cash as interest and principal. These theories suggest a negative relationship between leverage and investment but only for firms with no or little growth opportunities. $^{7}$

While both of the above theories predict a negative relationship between investment and leverage, they have different implications for high growth versus low growth firms. To test for differences in the role of leverage for high versus low growth opportunity firms, we use the following specification:

$$
\begin{aligned}
I_{i, t} / K_{i, t-1}= & \alpha+\lambda_{t}+\beta\left(\mathrm{CF}_{i, t} / K_{i, t-1}\right)+\delta Q_{i, t-1}+\eta \text { LEVERAGE }_{i, t-1}+\gamma D_{i, t-1} \\
& \times \operatorname{LEVERAGE~}_{i, t-1}+\varphi\left(\text { Sale }_{i, t-1} / K_{i, t-1}\right)+\mu_{i}+\varepsilon_{t, i}
\end{aligned}
$$

where $D$ is a dummy variable which is equal to 1 if Tobin's $Q>1$, and 0 otherwise.

The regression results are reported in Table 4. We find evidence supporting the theory that leverage has a disciplining role in preventing overinvestment. The estimated values of $\gamma$ are significant and positive for both measures of leverage as well as under different empirical methodologies; the point estimates of $\gamma$ range from about 0.1 to 0.2 . These results imply that leverage has a stronger negative impact on investment for firms with low growth opportunities than for firms with high growth opportunities. The other estimated coefficients are the same as those in the previous regressions in Table $2 .^{8}$ The estimated coefficients of the variables LEVERAGE and $D \times$ LEVERAGE in Table 4 could be better understood by comparing them with the results in Table 2 . In Table $4, D \times$ LEVERAGE has been added to the regression. Hence, for firms with $Q>1$, the coefficient for leverage is $\eta+\gamma$ and, for firms with $Q \leq 1$, it is $\eta$. The weighed average of the two should be equal to the coefficient for leverage in Table 2 . The summary statistics in Table 1 show that the 25 th percentile of $\mathrm{Q}$ is 1.00 , indicating that $25 \%$ of the sample has $Q \leq 1$. Therefore, the coefficient for leverage in Table 2 is equal to $0.25 \eta+0.75(\eta+\gamma)$. A simple calculation reveals that the results in Tables 2 and 4 are consistent.

\subsection{Summary}

In this section, we used various empirical models and measures of leverage to estimate the impact of leverage on investment. The statistical tests showed that a pooling regression is not appropriate and that it may underestimate the impact of leverage on investment. The fixed-effect model appeared most suitable. Our results confirm previous studies that leverage has a significantly negative impact on investment and that this negative relationship is robust across alternative models. In addition, leverage has a greater negative

\footnotetext{
7 Zwiebel (1996) and Novaes and Zingales (1995) have proposed a similar argument.

8 There are slight differences in the coefficients in Tables 2 and 4 due to rounding errors.
} 
Table 4

Growth opportunity, investment, and leverage

\begin{tabular}{|c|c|c|c|c|c|c|}
\hline & \multicolumn{3}{|c|}{ Leverage $=(\text { Long term debt/Total assets })_{t-1}$} & \multicolumn{3}{|c|}{ Leverage $=(\text { Total liabilities } / \text { Total assets })_{t-1}$} \\
\hline & Pooling & $\begin{array}{l}\text { Fixed } \\
\text { effect }\end{array}$ & $\begin{array}{l}\text { Random } \\
\text { effect }\end{array}$ & Pooling & $\begin{array}{l}\text { Fixed } \\
\text { effect }\end{array}$ & $\begin{array}{l}\text { Random } \\
\text { effect }\end{array}$ \\
\hline Intercept & $\begin{array}{l}0.229 * * * \\
(5.28)\end{array}$ & $\begin{array}{l}0.131 * * * \\
(5.66)\end{array}$ & $\begin{array}{l}0.201 * * * \\
(7.42)\end{array}$ & $\begin{array}{l}0.316^{* * *} \\
(6.62)\end{array}$ & $\begin{array}{l}0.205 * * * \\
(6.85)\end{array}$ & $\begin{array}{l}0.278 * * * \\
(8.99)\end{array}$ \\
\hline Leverage & $\begin{array}{l}-0.377 * * * \\
(6.58)\end{array}$ & $\begin{array}{l}-0.560 * * * \\
(7.17)\end{array}$ & $\begin{array}{l}-0.495 * * * \\
(6.88)\end{array}$ & $\begin{array}{l}-0.367 * * * \\
(7.24)\end{array}$ & $\begin{array}{l}-0.411 * * * \\
(7.76)\end{array}$ & $\begin{array}{l}-0.404 * * * \\
(8.71)\end{array}$ \\
\hline$D^{*}$ Leverage & $\begin{array}{l}0.200^{* * *} \\
(4.32)\end{array}$ & $\begin{array}{l}0.154 * * \\
(2.32)\end{array}$ & $\begin{array}{l}0.183 * * * \\
(2.85)\end{array}$ & $\begin{array}{l}0.108^{* * *} \\
(4.61)\end{array}$ & $\begin{array}{l}0.097 * * * \\
(3.10)\end{array}$ & $\begin{array}{l}0.109 * * * \\
(3.64)\end{array}$ \\
\hline Tobin's $\mathrm{Q}_{t-1}$ & $\begin{array}{l}0.042 * * * \\
(3.08)\end{array}$ & $\begin{array}{l}0.053 * * * \\
(13.45)\end{array}$ & $\begin{array}{l}0.048 * * * \\
(13.73)\end{array}$ & $\begin{array}{l}0.038^{* * *} \\
(2.88)\end{array}$ & $\begin{array}{l}0.053 * * * \\
(13.62)\end{array}$ & $\begin{array}{l}0.047 * * * \\
(13.47)\end{array}$ \\
\hline $\begin{array}{l}\text { Cash } \text { flow }_{t} / \\
\text { Total assets } \\
t-1\end{array}$ & $\begin{array}{l}0.015 \\
(0.96)\end{array}$ & $\begin{array}{l}0.021 * * * \\
(3.04)\end{array}$ & $\begin{array}{l}0.023 * * * \\
(3.96)\end{array}$ & $\begin{array}{l}0.015 \\
(1.01)\end{array}$ & $\begin{array}{l}0.020 * * * \\
(2.82)\end{array}$ & $\begin{array}{l}0.023 * * * \\
(3.88)\end{array}$ \\
\hline $\begin{array}{l}\text { Sale }_{t-1} / \\
\quad \text { Fixed assets } \\
t-1\end{array}$ & $\begin{array}{l}-0.003^{*} \\
(1.80)\end{array}$ & $\begin{array}{l}0.009 * * * \\
(7.07)\end{array}$ & $\begin{array}{l}0.003 * * * \\
(2.85)\end{array}$ & $\begin{array}{l}-0.001 \\
(0.78)\end{array}$ & $\begin{array}{l}0.010 * * * \\
(7.79)\end{array}$ & $\begin{array}{l}0.004 * * * \\
(4.29)\end{array}$ \\
\hline Hausman test & \multicolumn{3}{|c|}{$\mathrm{Chi}^{2}(23)=122.33 * * *$} & \multicolumn{3}{|c|}{$\mathrm{Chi}^{2}(23)=97.1 * * *$} \\
\hline $\begin{array}{l}\text { Observations } \\
\text { (Groups) }\end{array}$ & 6231 & $\begin{array}{l}6231 \\
(863)\end{array}$ & $\begin{array}{l}6231 \\
(863)\end{array}$ & 6231 & $\begin{array}{l}6231 \\
(863)\end{array}$ & $\begin{array}{l}6231 \\
(863)\end{array}$ \\
\hline Adj. $R^{2}$ & 0.055 & 0.090 & 0.086 & 0.066 & 0.090 & 0.086 \\
\hline
\end{tabular}

This table provides the empirical results of the effects of leverage on the investment of firms with high growth opportunities and low growth opportunities. $t$-statistics are provided in parenthesis below the coefficient estimates. For the pooling regression, the Huber/White/Sandwich estimators of standard errors are used. The Hausman specification test is used to test the fixed-effect model versus the random effect model. $D$ is a dummy variable which is equal to 1 if Tobin's Q is larger than 1 and 0 otherwise.

* Significant at the $10 \%$ level.

** Significant at the $5 \%$ level.

*** Significant at the $1 \%$ level.

impact on firms with low growth opportunities. In the next section, we address another important issue pertaining to the leverage-investment relationship, namely, the endogeneity problem in the relationship between leverage and investment.

\section{Two stage least squares regression}

Leverage may be affected by expected investment opportunities and, in the above regressions, we controlled for this effect by including the Tobin's Q variable in the baseline specification. However, such an approach may not adequately control for expected investment opportunities because Tobin's Q only reflects public information while the firm's leverage choice may also reflect inside information. ${ }^{9}$ One approach in dealing with this problem has been to test for differences in the effect of leverage in the firm's core business on investment decisions in its non-core business. ${ }^{10}$ The idea is that

9 Lehn et al. (1990) argue that leverage could be affected by growth opportunities. They show that firms with greater growth opportunities are more likely to consolidate control through dual-class recapitalizations than through leverage buyouts; the implication is that growth opportunities could affect firm leverage.

10 See Lang et al. (1996). 
leverage in the firm's non-core business should be less affected by growth opportunities than that in its core business and, therefore, if leverage proxies for investment opportunities, we should not observe a strong relationship between the firm's leverage and its noncore investment. This approach, however, has its limitations. First, it is hard to classify core and non-core segments appropriately to ensure sufficiently different growth opportunities. Second, there might be sample bias since segment files only cover a partial sample of firms and provide limited information about segment investments and assets.

We adopt an instrumental variable approach to deal with the endogeneity problem pertaining to the relationship between leverage and investment. The instrumental variable for leverage that we use is the proportion of the value of tangible assets to total assets. Using tangibility as an instrumental variable can be justified on the basis of the following arguments: first, bankruptcy costs are an important determinant of the firm's leverage level and tangible assets tend to reduce bankruptcy costs and increase the use of leverage. Therefore, the tangibility of assets should be highly correlated with the firm's leverage level. Second, tangibility of assets is not highly correlated with the firm's investment opportunities. We measure tangibility of assets by the value of property, plant, and equipment, plus the value of inventory divided by total assets. The correlation between leverage and asset tangibility is 0.613 , while the correlation between investment and tangible assets is only -0.009 , suggesting that tangibility of assets is an appropriate instrumental variable. We regress leverage on the tangibility of assets and then use the predicted value as a proxy for leverage in the second-stage regression of the investment equation.

Table 5 reports the results from the instrumental variable approach and shows that the negative relationship between leverage and investment is robust for different

Table 5

Instrumental variable estimation of investment equation

\begin{tabular}{|c|c|c|c|}
\hline & \multicolumn{3}{|c|}{ Total liabilities/Total asset } \\
\hline & Pooling & Fixed effect & Random effect \\
\hline Intercept & $0.070(0.92)$ & $0.577 * * *(5.60)$ & $0.352 * * *(3.77)$ \\
\hline IV(Leverage $\left.t_{t-1}\right)$ & $-0.139(1.16)$ & $-1.082 * * *(6.45)$ & $-0.549 * * *(3.82)$ \\
\hline$D^{*} \operatorname{IV}\left(\right.$ Leverage $\left._{t-1}\right)$ & $0.111 * * *(5.15)$ & $0.113 * * *(3.77)$ & $0.129 * * *(4.52)$ \\
\hline Tobin's $\mathrm{Q}_{t-1}$ & $0.047 * * *(4.31)$ & $0.057 * * *(10.28)$ & $0.051 * * *(10.92)$ \\
\hline Cash flow $_{t} /$ Total asset $_{t-1}$ & $0.020(1.78)$ & $0.022 * * *(2.99)$ & $0.024 * * *(4.05)$ \\
\hline Sale $_{t-1} /$ Fixed asset $t_{t-1}$ & $-0.002(1.13)$ & $0.010 * * *(8.08)$ & $0.002 * *(2.11)$ \\
\hline Hausman test & $\mathrm{Chi}^{2}(22)=122.10 * * *$ & & \\
\hline Observations (Groups) & $5002(731)$ & $5002(731)$ & $5002(731)$ \\
\hline Adj. $R^{2}$ & 0.053 & 0.084 & 0.073 \\
\hline
\end{tabular}

This table provides the empirical results of the effects of leverage on investment using the instrumental variable approach. $t$-statistics are provided in parenthesis below the coefficient estimates. For the pooling regression, the Huber/White/Sandwich estimators of standard errors are used. The Hausman specification test is used to test the fixed-effect model versus the random effect model. $D$ is a dummy variable which is equal to 1 if Tobin's $\mathrm{Q}$ is larger than 1 and 0 otherwise. The instrumental variable for leverage is the tangibility of assets in total assets. The measure of tangibility of assets is: (Property, Plant and Equipment + Inventory)/Total asset.

* Significant at the $10 \%$ level.

** Significant at the 5\% level.

*** Significant at the $1 \%$ level. 
Table 6

Regression analysis using industry-adjusted variables

\begin{tabular}{|c|c|c|c|c|c|c|}
\hline & \multicolumn{3}{|c|}{$\underline{\text { Leverage }}=(\text { Long term debt } / \text { Total assets })_{t-1}$} & \multicolumn{3}{|c|}{$\underline{\text { Leverage }}=(\text { Total liabilities } / \text { Total assets })_{t-1}$} \\
\hline & Pooling & Fixed & Random & Pooling & Fixed & Random \\
\hline Intercept & $\begin{array}{l}0.130 * * * \\
(4.69)\end{array}$ & $\begin{array}{l}0.062 * * * \\
(3.47)\end{array}$ & $\begin{array}{l}0.125^{* * * *} \\
(5.38)\end{array}$ & $\begin{array}{l}0.126^{* * *} \\
(4.58)\end{array}$ & $\begin{array}{l}0.056^{* * * *} \\
(3.12)\end{array}$ & $\begin{array}{l}0.116^{* * * *} \\
(5.00)\end{array}$ \\
\hline Leverage & $\begin{array}{l}-0.182 * * * \\
(3.37)\end{array}$ & $\begin{array}{l}-0.397 * * * \\
(6.88)\end{array}$ & $\begin{array}{l}-0.359 * * * \\
(6.75)\end{array}$ & $\begin{array}{l}-0.176^{* * * *} \\
(3.35)\end{array}$ & $\begin{array}{l}-0.282 * * * \\
(6.29)\end{array}$ & $\begin{array}{l}-0.261 * * * \\
(6.39)\end{array}$ \\
\hline Tobin's $\mathrm{Q}_{t-1}$ & $\begin{array}{l}0.042^{* * * *} \\
(2.97)\end{array}$ & $\begin{array}{l}0.047 * * * \\
(0.004)\end{array}$ & $\begin{array}{l}0.044 * * * \\
(12.36)\end{array}$ & $\begin{array}{l}0.041^{* * *} \\
(2.87)\end{array}$ & $\begin{array}{l}0.047 * * * \\
(12.06)\end{array}$ & $\begin{array}{l}0.044 * * * \\
(12.66)\end{array}$ \\
\hline 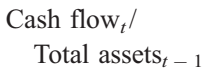 & $\begin{array}{l}0.014 \\
(0.93)\end{array}$ & $\begin{array}{l}0.018 * * * \\
(2.59)\end{array}$ & $\begin{array}{l}0.020^{* * * *} \\
(3.40)\end{array}$ & $\begin{array}{l}0.013 \\
(0.90)\end{array}$ & $\begin{array}{l}0.017 * * \\
(2.53)\end{array}$ & $\begin{array}{l}0.020 * * * \\
(3.36)\end{array}$ \\
\hline $\begin{array}{l}\text { Sale }_{t-1} / \\
\quad \text { Fixed assets } \\
t-1\end{array}$ & $\begin{array}{l}-0.001 \\
(0.26)\end{array}$ & $\begin{array}{l}0.009 * * * \\
(6.75)\end{array}$ & $\begin{array}{l}0.004^{* * * *} \\
(4.18)\end{array}$ & $\begin{array}{l}0.0001 \\
(0.06)\end{array}$ & $\begin{array}{l}0.009 * * * \\
(7.29)\end{array}$ & $\begin{array}{l}0.005^{* * * *} \\
(4.92)\end{array}$ \\
\hline Hausman test & \multicolumn{3}{|c|}{$\mathrm{Chi}^{2}(22)=76.42 * * *$} & \multicolumn{3}{|c|}{$\mathrm{Chi}^{2}(22)=72.51 * * *$} \\
\hline $\begin{array}{l}\text { Observations } \\
\text { (Groups) }\end{array}$ & 6231 & $\begin{array}{l}6231 \\
(863)\end{array}$ & $\begin{array}{l}6231 \\
(863)\end{array}$ & 6231 & $\begin{array}{l}6231 \\
(863)\end{array}$ & $\begin{array}{l}6231 \\
(863)\end{array}$ \\
\hline Adj. $R^{2}$ & 0.037 & 0.067 & 0.066 & 0.038 & 0.066 & 0.066 \\
\hline
\end{tabular}

This table provides the empirical results of the effects of leverage on investment using industry-adjusted variables. $t$-statistics are provided in parenthesis below the coefficient estimates. The Huber/White/Sandwich estimators of standard errors are used. The Hausman specification test is used to test the fixed-effect model versus the random effect model.

* Significant at the $10 \%$ level.

** Significant at the 5\% level.

*** Significant at the $1 \%$ level.

models. ${ }^{11}$ The estimated coefficient of leverage is -0.139 in the pooling regression, -1.082 in the fixed effect regression, and -0.549 in the random effect regression. The coefficients of the interactive term between the growth dummy variable and leverage range from 0.111 to 0.129 . Both point estimates are statistically significant, suggesting that leverage has a significantly greater impact on the investment decision of low investment opportunity firms than that of high investment opportunity firms. These results are similar to our previous results and suggest that endogeneity cannot explain away the negative relationship between leverage and investment.

\section{Robustness test}

We have shown that our results are robust with respect to alternative models and measurements of variables. As a further test of the robustness of the estimates, we first control for industry effects and then restrict the analysis to manufacturing firms.

There may be significant heterogeneity in investment behavior across different industries and hence it is important to control for industry effects. In the above panel model, industry effects were subsumed under individual firm effects. To check the robustness of our previous results, we use the industry median to adjust the variables in

\footnotetext{
11 Though not reported here, results using (total assets - intangible assets)/total assets as the measure of tangible assets and long-term debt/total asset as the measure leverage produce very similar results.
} 
Table 7

Regression analysis using firms in manufacturing industries

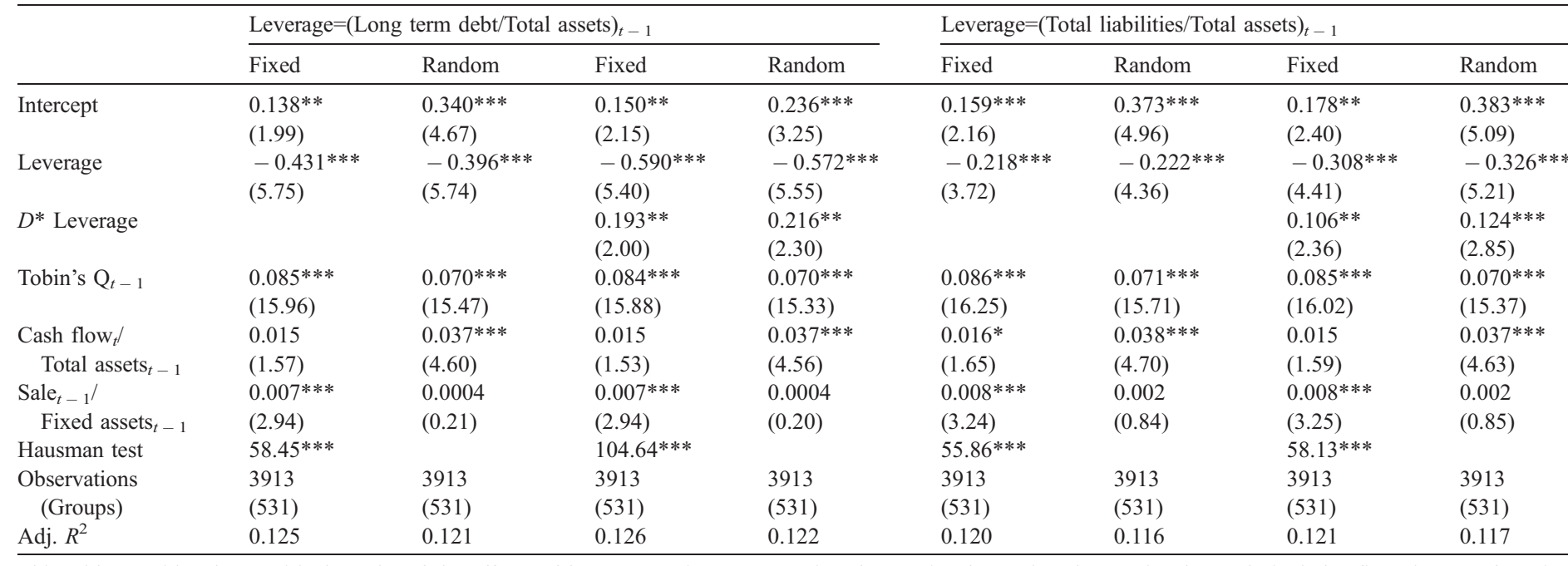

This table provides the empirical results of the effects of leverage on investment using the restricted sample. The restricted sample includes firms in manufacturing industries (SIC codes between 1000 and 3990). $t$-statistics are provided in parenthesis below the coefficient estimates. The Huber/White/Sandwich estimators of standard errors are used. The Hausman specification test is used to test the fixed-effect model versus the random effect model.

* Significant at the $10 \%$ level.

** Significant at the $5 \%$ level.

*** Significant at the $1 \%$ level. 
the investment equation. Each variable is adjusted by deducting the median of the industry to which the firm belongs; this allows us to control industry heterogeneity in terms of average scales. Table 6 presents the results of the regression of the investment equation using the industry-adjusted variables in terms of deviation from the industry median. $^{12}$

The results of Table 6 are similar to the previous ones. The estimated coefficients are slightly less than those in the case without industry adjustments but the signs and significance levels of the coefficients do not change. Again we find a significant and negative relationship between leverage and investment, which implies that firms with greater leverage than the industry median invest less than those with less leverage than the industry median.

We also do estimations by restricting our sample to firms in manufacturing industries. ${ }^{13}$ The rationale for using manufacturing firms is that the investment behavior of these firms is less likely to be affected by regulations (unlike financial firms) and by the nature of their activities (unlike utility firms). The estimated results of this restricted sample are reported in Table 7.

The results of the full sample and of the restricted sample are highly similar. None of the significant coefficients changes sign. The results confirm our earlier findings that leverage has a negative impact on investment and that this impact is stronger for firms with low growth opportunities.

\section{Conclusions}

This paper extended earlier empirical studies on the relationship between leverage and investment in several important dimensions, including the treatment of the endogeneity problem. It examined the relationship for Canadian companies, a hitherto unexamined data set for this purpose. Since Canada has a similar institutional environment to the US, this study allows us to compare results for two similar yet quite independent samples. Using a panel of Canadian publicly traded firms between 1982 and 1999, we examined whether financing considerations (as measured by the extent of financial leverage) affect firm investment decisions inducing underinvestment or overinvestment incentives. We found that leverage is negatively related to the level of investment, and that this negative effect is significantly stronger for firms with low growth opportunities than those with high growth opportunities. The negative effect is large and robust to different measures of leverage, to different samples, and to alternative econometric methodologies. Our results provide support to agency theories of corporate leverage, and especially to the theory that leverage has a disciplining role for firms with weak growth opportunities.

\footnotetext{
12 Another way of controlling for industry effects is to use industry dummy variables. However, since we are interested in whether firms with high leverage have lower growth than those with low leverage in the same industry, it is more appropriate to use the industry adjustment approach. A similar argument is made by Lang et al. (1996).

13 The manufacturing industries are grouped from SIC 1000 to SIC 3990.
} 


\section{Appendix A. Variable definitions}

Investment $=$ Net investment $/$ Lagged net fixed assets $=\{$ Capital expenditure $($ Compustat item 128) - Depreciation (Compustat item 14) $\} /$ Lagged net fixed assets.

Leverage $1=$ Total liabilities $($ Compustat item 181)/Total assets (Compustat item 6) Leverage $2=$ Long term debt (Compustat item 9)/Total assets (Compustat item 6)

Cash flow $=$ Earnings before extraordinary items $($ Compustat item 18) + Depreciation (Compustat item 14)

Tobin's $\mathrm{Q}=\{$ Total liabilities + Market value of the common stocks (Compustat item $25 \times$ Compustat item 199) + Estimated market value of the preferred Stocks $(10 \times$ Compustat item 10) $\} /\{$ Book value of total assets (Compustat item 6$)\}$. Sale $=$ Net sale (Compustat item 12)/Lagged net fixed assets .

\section{References}

Aivazian, V.A., Callen, J.L., 1980. Corporate leverage and growth: the game-theoretic issues. Journal of Financial Economics 8, 379-399.

Breusch, T., Pagan, A., 1980. The Lagrange multiplier test and its applications to model specification in econometrics. Review of Economic Studies 47, 239-253.

Grossman, S., Hart, O., 1982. Corporate financial structure and managerial incentives. In: McCall, J. (Ed.), The Economics of Information and Uncertainty. University of Chicago Press, Chicago, pp. 107-140.

Hausman, J.A., 1978. Specification tests in econometrics. Econometrica 46, 1251-1271.

Himmelberg, C.P., Hubbard, R.G., Palia, D., 1999. Understanding the determinants of managerial ownership and the link between ownership and performance. Journal of Financial Economics 53, 353-384.

Jensen, M.C., 1986. Agency cost of free cash flow, corporate finance, and take-overs. American Economic Review 76, 323-329.

Lang, L.E., Ofek, E., Stulz, R., 1996. Leverage, investment and firm growth. Journal of Financial Economics 40, $3-29$.

Lehn, K., Netter, J., Poulsen, A., 1990. Consolidating corporate control: the choice between dual-class Recapitalizations versus leverage buyouts. Journal of Financial Economics 27, 557-580.

McConnell, J.J., Servaes, H., 1995. Equity ownership and the two faces of debt. Journal of Financial Economics $39,131-157$.

Modigliani, F., Miller, M.H., 1958. The cost of capital, corporation finance, and the theory of investment. American Economic Review 53, 433-443.

Myers, S., 1977. Determinants of corporate borrowing. Journal of Financial Economics 5, 147-175.

Novaes, W., Zingales, L., 1995. Capital structure choice when managers are in control: entrenchment vs. efficiency. NBER working paper No. 5384.

Opler, T.C., Titman, S., 1994. Financial distress and corporate performance. Journal of Finance 49, $1015-1104$.

Stulz, R.M., 1990. Managerial discretion and optimal financing policies. Journal of Financial Economics 26, 3-27.

Zwiebel, J., 1996. Dynamic capital structure under managerial management. American Economic Review 86, 1197-1215. 